\title{
The Effect of Selenium Supplementation in the Prevention of DNA Damage in White Blood Cells of Hemodialyzed Patients: A Pilot Study
}

\author{
Bronislaw A. Zachara • Jolanta Gromadzinska • \\ Jadwiga Palus $\cdot$ Zbigniew Zbrog • Rafal Swiech • \\ Ewa Twardowska $\cdot$ Wojciech Wasowicz
}

Received: 31 May 2010 / Accepted: 11 July 2010 /

Published online: 27 July 2010

(C) The Author(s) 2010. This article is published with open access at Springerlink.com

\begin{abstract}
Patients with chronic kidney disease (CKD) have an increased incidence of cancer. It is well known that long periods of hemodialysis (HD) treatment are linked to DNA damage due to oxidative stress. In this study, we examined the effect of selenium (Se) supplementation to CKD patients on HD on the prevention of oxidative DNA damage in white blood cells. Blood samples were drawn from $42 \mathrm{CKD}$ patients on HD (at the beginning of the study and after 1 and 3 months) and from 30 healthy controls. Twenty-two patients were supplemented with $200 \mu \mathrm{g}$ Se (as Se-rich yeast) per day and 20 with placebo (baker's yeast) for 3 months. Se concentration in plasma and DNA damage in white blood cells expressed as the tail moment, including single-strand breaks (SSB) and oxidative bases lesion in DNA, using formamidopyrimidine glycosylase (FPG), were measured. Se concentration in patients was significantly lower than in healthy subjects $(P<0.0001)$ and increased significantly after 3 months of Se supplementation $(P<0.0001)$. Tail moment (SSB) in patients before the study was three times higher than in healthy subjects $(P<0.01)$. After 3 months of Se supplementation, it decreased significantly $(P<0.01)$ and was about $16 \%$ lower than in healthy subjects. The oxidative bases lesion in DNA (tail moment, FPG) of HD patients at the beginning of the study was significantly higher $(P<0.01)$ compared with controls, and 3 months after Se supplementation it was 2.6 times lower than in controls $(P<0.01)$. No changes in tail moment was observed in the placebo group. In conclusion, our study shows that in CKD patients on HD, DNA damage in white blood cells is higher than in healthy controls, and Se supplementation prevents the damage of DNA.
\end{abstract}

B. A. Zachara $\cdot$ J. Gromadzinska $\cdot$ J. Palus $\cdot$ E. Twardowska $\cdot$ W. Wasowicz

Department of Toxicology and Carcinogenesis, Nofer Institute of Occupational Medicine, Lodz, Poland

Z. Zbrog $\cdot$ R. Swiech

B. Braun Avitum Dialysis Center, Lodz, Poland

B. A. Zachara $(\bowtie)$

Higher School of Health Sciences, 33/67 Nowodworska, 85-120 Bydgoszcz, Poland

e-mail: bronzach1@gmail.com 
Keywords Chronic kidney disease $\cdot$ Comet assay $\cdot$ DNA damage $\cdot$ Hemodialysis ·

Selenium supplementation

\section{Introduction}

Chronic kidney disease (CKD) is an important cause of morbidity and mortality all over the world [1]. Hemodialysis (HD) is the most common form of treatment for endstage renal disease (ESRD), and is associated with considerable mortality due to cardiovascular disease, cancer and others [2]. Patients with CKD undergoing HD are potentially at risk for deficiency of essential trace elements and excess of toxic elements, both of which can affect health [2,3]. Such trace elements as selenium, zinc and copper, bound to the active sites of some proteins, play a key role in multiple biological systems, including defense against oxidation [4] and detoxify the organism from free radicals which are responsible, among others, for cancer development [5]. An excellent systematic review, published recently by Tonelli et al. [3], has shown that, compared with healthy subjects, HD patients have significantly lower blood levels of selenium, zinc and manganese. Available data suggested that toxic elements (cadmium, chromium, lead, vanadium and aluminum) were higher in HD patients compared with healthy controls $[1,3]$. Chronic exposure to toxic elements produces, among others, progressive tubulointerstitial nephropathy that develops and leads to kidney failure [1]. The levels of toxic elements in blood of patients before HD were found to be higher than in blood after dialysis session. During HD toxic elements and metabolic waste products are removed from the body [1].

There is increasing evidence that oxidative stress leads to detrimental biochemical reactions and is an important contributing factor in several chronic diseases including cancer [6-8]. In living cells, there is a steady formation of DNA lesions. A substantial number of these lesions are formed by endogenous factors that damage DNA on a continuous basis [9].

Oxidative damage to DNA occurs in all aerobic cells. In higher animals and humans, it increases with age, and although physiological repair systems are available, some of the damage is irreversible, and thus represents a contributing factor in cancer development [7].

Nutrients constitute an important aspect of the antioxidant defense system with which humans have evolved [8]. Se which is the focus of this study has, among others, two fundamental roles in cancer prevention: as a component of antioxidant defenses either as an agent able to scavenge free radicals or as an essential constituent of antioxidant enzymes such as glutathione peroxidases (GSH-Px) [10-12].

The aim of the present study was to determine the effect of Se supplementation to CKD patients on HD on DNA damage in white blood cells measured by the alkaline comet assay, the most sensitive and accurate method [13].

\section{Materials and Methods}

Patients and Controls

Forty-two CKD patients treated with regular HD were studied in a randomized, doubleblind, placebo-controlled trial. Selenium (as Se-rich yeast, Pharma Nord, Bioselenium, 
Denmark) was supplemented to 22 patients (mean age, 59.6 \pm 10.4 yrs) for 3 months with $200 \mu \mathrm{g}$ Se/day, and placebo (baker's yeast, Pharma Nord) was administered to 20 patients (mean age, 55.8 $\pm 12.5 \mathrm{yrs}$ ). The patients were dialyzed three times a week for $4 \mathrm{~h}$. The

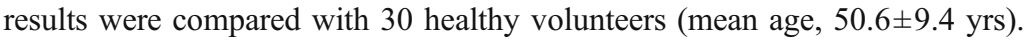

\section{Methods}

Blood samples were drawn from all patients (before HD session) and controls into vacutainer tubes containing lithium heparin as anticoagulant. After centrifugation $\left(+4^{\circ} \mathrm{C}\right.$, $5,000 \mathrm{rpm}, 10 \mathrm{~min}$ ), the plasma was harvested and stored at $-20^{\circ} \mathrm{C}$ until analysis. Creatinine was determined by routine laboratory Jaffy method using a kit produced by Cormay (Lublin, Poland). Plasma Se concentration was determined by the graphite furnace atomic absorption spectrometry according to the method of Neve et al. [14] using Unicam 989 QZ Solaar apparatus and the values were expressed as nanogram per milliliter. The accuracy of the method was checked with serum reference material (Nycomed, Oslo, Norway, batch No. 605113). The mean Se level of reference serum was $78.0 \mu \mathrm{g} / \mathrm{L}$, while that obtained in our laboratory was $77.4 \pm 5.0 \mu \mathrm{g} / \mathrm{L}$.

DNA damage, including the single-strand breaks (SSB) and alkali labile sites (ALS), were detected using the alkaline single cell gel electrophoresis (SCGE, comet assay) according to the method of Singh et al. [15] as modified by McKelvey-Martin et al. [16] and adapted in our laboratory [17]. In brief, the cells $(100 \mu \mathrm{L}$ of whole blood in RPMI 1640 medium) were embedded in agarose gel and lysed in cold lysing solution of salts and detergents for at least $1 \mathrm{~h}$. Then DNA was unwound in the alkaline electrophoresis solution (1 mM Na2EDTA, $300 \mathrm{mM} \mathrm{NaOH}, \mathrm{pH}>13$ ) to produce single-stranded DNA and to express ALS and SSB and under the same alkaline conditions it was electrophoresed (30 min. $25 \mathrm{~V}$ and $300 \mathrm{~mA}$ ). The alkali in the gels were neutralized by rinsing three times with $0.4 \mathrm{M}$ Tris buffer $(\mathrm{pH}=7.5)$, dried and stored for staining with fluorescent dye $(5 \mu \mathrm{g} / \mathrm{mL}$ DAPI). The oxidative bases lesion in DNA was identified using formamidopyrimidine glycosylase (FPG) enzyme which converts oxidized bases [18]. After lysis the slides were washed three times with enzyme buffer, $\mathrm{pH}=8$ and incubated with FPG in this buffer (or buffer alone as a control) for $30 \mathrm{~min}$, at $37^{\circ} \mathrm{C}$. They were then electrophoresed, neutralized, and stained as described above. To assess the level of DNA fragmentation, the comets were analyzed under fluorescence microscopy (Olympus BX40, Tokyo, Japan) with image analysis system (Lucia Comet Assay, Precoptic Co.) determining the tail length and the tail moment (tail length $\times$ tail\% DNA/100), which expresses both the migration of the various DNA fragments and their relative amounts of DNA. The tail moment was used as an indicator of DNA damage.

The study protocol was approved by the Institute of Occupational Medicine Ethics Commission for Medical Research No. 18/2003. The nature and purpose of the study was explained to the participants and their written consent was obtained.

\section{Statistical Analysis}

Comparisons of the levels under study at three time points (before the study, 1 and 3 months after the study) were made by means of the multivariate analysis of variance [19]. When significant differences were obtained between the groups, the differences were tested at all time points. The tests were based on Shapiro-Wilks' statistics, significance being set at 0.05 . All statistics were conducted using the STATA 9 package (StataCorp-LP, TX, USA). 


\section{Results}

Plasma Se concentration in CKD patients on HD studied by us, at the beginning of the study (both groups taken together: supplemented with Se and with placebo; $40.6 \pm 10.4 \mathrm{ng} / \mathrm{mL}$ ) was significantly lower as compared with healthy subjects $(52.7 \pm 9.7 \mathrm{ng} / \mathrm{mL} ; P<0.0001$; Fig. 1$)$. After 1 and 3 months of Se supplementation the element concentration increased significantly to 94.6 and $115 \mathrm{ng} / \mathrm{mL} ; P<0.0001$. In the group treated with placebo, Se concentration was unchanged during the whole period of the study. The levels of DNA single-strand breaks, expressed as the tail moment, were three times higher in both groups of HD patients before tablets supply, $(0.73 \pm 0.84)$ as compared with the control group $(0.25 \pm 0.24: P<0.01)$. After 1 month of Se supplementation the tail moment (expressed as $\mathrm{SSB})$ decreased significantly from $0.9 \pm 1.07$ to $0.37 \pm 0.38(P<0.02$; Fig. 2$)$. Within the next 2 months the tail moment of Se-supplemented patients underwent further decrease to $0.21 \pm$ 0.18 . This value was about $16 \%$ lower than in healthy subjects. The differences between $\mathrm{HD} 3+\mathrm{Se}$ and HD0+Se values were statistically significant $(P<0.01)$.

No changes in the tail moment were observed in the placebo group. At the third month the tail moment in HD patients supplemented with Se was almost two times lower as compared with the placebo group, but the difference was statistically non significant. The oxidative bases lesion in DNA of white blood cells of both groups of HD patients taken together at the beginning of the study, expressed in FPG, was significantly higher (1.28 $1.60)$ than that of healthy subjects $(0.55 \pm 0.45: P<0.01$; Fig. 3$)$. Within the 3 -month study period the lesion in the placebo group did not change significantly, while in the Sesupplemented group it decreased significantly from $1.12 \pm 1.01$ to $0.43 \pm 0.52(P<0.01)$. At the third month, the tail moment (FPG) in Se-supplemented group was 2.6 times lower as compared with the placebo group $(P<0.05)$.

\section{Discussion}

The results obtained in this study indicate that Se concentration in plasma of the end-stage kidney disease (ESKD) patients on HD is significantly lower as compared with healthy subjects. Low Se levels in body fluids can be due to the malnutrition observed in cancer patients [20]. It has been shown that higher Se status reduces the risk of cancer [21] and is

Fig. 1 Selenium concentration in plasma of healthy subjects and chronic kidney disease patients on hemodialysis supplied with placebo (white columns) and selenium (dark columns; the values of both subgroups were taken together) at the beginning of the study $(H D O)$ and after 1 (HD 1) and 3 months (HD 3). Statistics: $a$, HD 0 (both subgroups) vs. controls, $P<0.0001$; $b$, HD $1+$ Se vs, HD $0+\mathrm{Se}$, $P<0.0001 ; c$, HD 3+Se vs. HD $1+$ Se, $P<0.01$

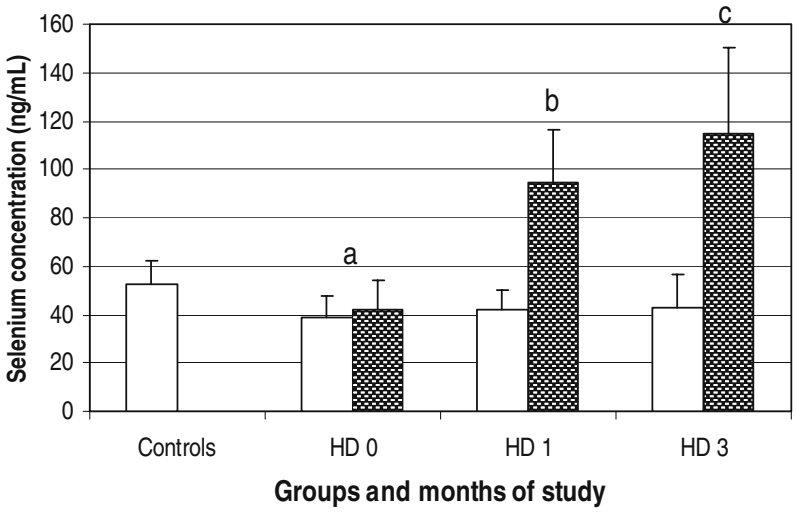




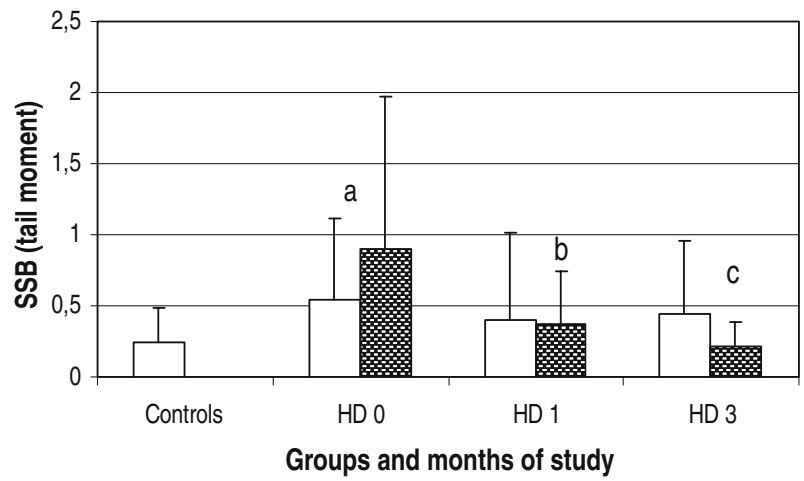

Fig. 2 Single-strand breaks of DNA (presented as tail moment) in white blood cells of healthy subjects and chronic kidney disease patients on hemodialysis supplied with placebo (white columns) and selenium (dark columns; the values of both subgroups were taken together) at the beginning of the study $(H D 0)$ and after $1(H D 1)$ and 3 months (HD 3). Statistics: $a$, HD 0 both subgroups vs. controls, $P<0.01 ; b$, HD $1+\mathrm{Se}$ vs. HD $0+\mathrm{Se}, P<0.02 ; c$, HD $3+$ Se vs. HD $0+\mathrm{Se}, P<0.01$

associated with lower mortality [22, 23]. Thus, low levels of Se may promote the development of cancer in those patients.

Our data on low Se concentration in CKD patients are consistent with those obtained by many other authors $[10,24]$ and with our previous studies $[25,26]$ in which we have shown that not only Se concentration but also GSH-Px activity in plasma of HD patients is significantly lower than in controls. Se supplementation to those patients caused an increase in Se concentration in blood components and a small increase or no effect on plasma GSHPx activity, depending on the stage of the disease [10, 27]. Several epidemiological studies suggest that higher Se concentration reduces the risk of cancer [21] and increases DNA repair capacity in human fibroblasts damaged by hydrogen peroxide [28].

It is believed that people with low values of various antioxidants, including Se (which is incorporated into GSH-Px, and some other proteins), are prone to develop cancer. Particular

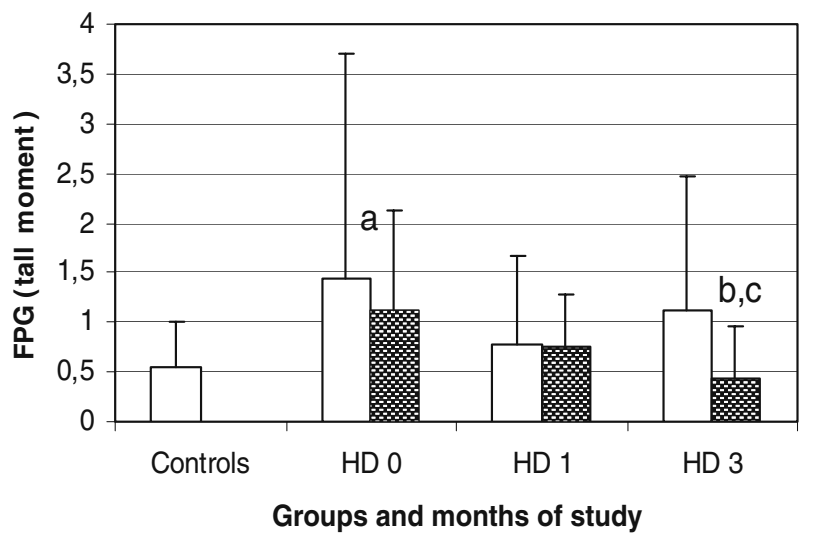

Fig. 3 Formamidopyrimidine glycosylase (presented as tail moment) in white blood cells of healthy subjects and chronic kidney disease patients on hemodialysis supplied with placebo (white columns) and selenium (dark columns) at the beginning of the study $(H D O)$ and after $1(H D 1)$ and 3 months $(H D$ 3). Statistics: $a$, HD 0 (both subgroups) vs. controls, $P<0.01 ; b$, HD $3+$ Se vs. HD $0+$ Se, $P<0.01 ; c$, HD $3+$ Se vs. HD $3-$ Se, $P<0.05$ 
interest in Se came in the wake of clinical studies showing that dietary supply of organic Se, in the form of yeast enriched with this trace element, decreased the overall incidence of cancer twofold, above all of prostate, lung and colorectal cancers [29]. Se and antioxidants have been suggested to scavenge free radicals, and prevent their interactions with cellular DNA [30]. A number of known antioxidants contribute to the defense against reactive oxygen species (ROS) in the organism. Small molecule dietary antioxidants (vitamin A [31], C [32-35], E [32, 33, 35-37], $\beta$-carotene [32, 34]), and some others [30, 31, 38, 39] have shown a significant protection against oxidative stress measured by different methods. When investigating the involvement of oxidative stress in cancer development, the important question is: what are the most appropriate biomarkers of oxidative stress and what is the best way to measure them?

Commonly used biomarkers of oxidative stress include measurement of oxidative damage to DNA [40]. They can be assessed by determination of 8-oxo-7,8-dihydro-2'deoxyguanosine (8-oxodG) level in cellular DNA and the determination of urinary excretion of oxidatively modified bases/nucleosides [40]. Worthy of attention is the fact that over the past decade another method - the comet assay - has become one of the standard methods for assessing DNA damage and repair [41], being free of artifacts. It is one of the most sensitive and accurate methods. It is also a valuable tool in assessing the role of oxidative stress in human diseases, and in monitoring the effects of dietary antioxidants [13]. For that reason, we used the comet assay method which reflects the content of DNA in the comet tail as well as the length of comet tail [42].

Our results show that the level of DNA damage in white blood cells in patients on HD is significantly higher than that in healthy subjects. These data are in accord with the finding published quite recently by Ribeiro et al. [43] who have assessed the level of DNA damage by measuring the tail moment in various organs of Wistar rats in which the chronic renal failure was obtained by submitting the animals to 5/6 kidney mass ablation by ligation of renal artery branches. The authors have shown that chronic kidney disease contributed to the damage of DNA not only in leukocytes but also in other organs: liver, heart and kidney.

There are few studies on the effect of some antioxidants (except selenium) on the oxidative damage of genetic material in patients with CKD nondialyzed and on HD [33, 36-38, 44-46]. Tarng et al. [33], Domenici et al. [37]; and quite recently, Puchades Montesa et al. [44] have shown that the level of 8-hydroxy-2'-deoxyguanosine (8OHdG; another biomarker of oxidative stress) of leukocyte DNA in the chronic hemodialysis patients is higher than in controls. Kan et al. [36] and Domenici et al. [37] have demonstrated, using the alkaline comet assay, higher levels of DNA single-strand breaks in patients undergoing HD than in the controls. Stopper et al. [47] have shown that an averaged level of DNA damage in peripheral blood lymphocytes of CKD patients was higher than that in healthy controls and it increased in patients on maintenance HD. Increased level of DNA damage in leukocytes of CKD patients may lead to increased premature cellular aging, as well as enhancing cancer development [33, 44-46]. This is particularly true of subjects in ESKD and on HD [48, 49].

In the literature, there is relatively little data on the effect of some antioxidants on DNA in white blood cells of patients on HD. Supplementation of the antioxidants has been suggested to scavenge free radicals and reduce the DNA damage [32, 38, 50], and thus may prevent the development of cancer [30, 38, 50]. The effect of Se on DNA damage and cancer development in patients with $\mathrm{CKD}$ has not been studied so far. It is thought that $\mathrm{Se}$ exerts its physiological effects mostly in the form of selenium-containing proteins (selenoproteins). At least 25 selenoproteins have been identified, including GSH-Px, 
selenoprotein $\mathrm{P}$, thioredoxin reductase, iodothyronine deiodinase, selenophosphate synthetase and some others [51-53]. GSH-Px, selenoprotein P and thioredoxin reductase are the major components of the body antioxidant system $[21,54]$ and changes in expression of some of them have been observed in different forms of cancer [51, 55]. Grotto et al. [56] found negative correlation $(r=-0.559 ; P<0.05)$ between GSH-Px activity and DNA lesion (measured by comet assay) showing that the lower GSH-Px activity the greater the DNA damage. Increased GSH-Px activity can destroy ROS in the body and thus prevents DNA damage.

As noted above, we did not find any article on the role of Se supplementation and the protection of DNA damage in patients with CKD. However, there is some data on the effect of Se supplementation in the prevention of DNA damage in patients with prostate cancer [57-59] and breast cancer [40, 60].

Very interesting results concerning the protective effect of Se against oxidative damage to DNA in leukocytes of BRCA1 mutation carriers have recently been presented by Olinski's group [40]. The authors demonstrated that BRCA1 deficiency contributes to 8oxodG accumulation in cellular DNA, which in turn may be a factor responsible for cancer development in women with mutations, and that the risk to developed breast cancer in BRCA1 mutation carriers may be significantly reduced in Se-supplemented patients (300 $\mu \mathrm{g} /$ day) [60].

The present study has shown that Se supplementation to HD patients reduced the level of DNA damage, as demonstrated by the progressive reduction of SSB and FPG in white blood cells. Longer-term of Se supplementation to HD patients enhanced the protection of the DNA against ROS, resulting the reduction of the SSB and FPG levels. To the best of our knowledge, the current work is the first study to demonstrate the protective effect of Se supplemented to HD patients on DNA in the white blood cells. Our patients were supplemented with $200 \mu \mathrm{g}$ Se/day in the form of Se yeast. This dose and form of Se was chosen because it had been shown that the inorganic form of Se is more toxic and less available than the organic form [61, 62]. The best form of Se for humans is the organic form - the selenomethionine (SeMet) $[12,63,64]$ and especially SeMet incorporated in yeast $[65,66]$. It was calculated that Se yeasts contain $90 \%$ of the total $\mathrm{Se}$ in the form of SeMet $[12,67]$. It has been shown that SeMet enhances DNA repair and protects cells against DNA damage $[68,69]$. It is worthy to note, in the context of what has recently been suggested by Schrauzer [65], that selenium yeast, in which the SeMet is protein bound, shows a better effect than synthetic SeMet, since Se incorporated into protein is better protected from oxidation when exposed to air in the pure state. SeMet present in yeast is protein-bound form, that is similar to its normal presence in food. Se present in SeMet may alter its uptake, transport, tissue distribution, metabolism and excretion.

In conclusion our results show that in CKD patients on $\mathrm{HD}$, Se concentration in plasma is lower and the level of DNA damage in white blood cells is higher than in healthy controls. Se supplementation to such patients prevents the damage of DNA as demonstrated by the progressive reduction of this level of SSB DNA and FPG DNA in white blood cells. Se supplementation to HD patients has a protective effect against oxidative DNA damage in white blood cells.

Acknowledgements This study was financially supported by the State Committee for Scientific Research (KBN), Warsaw, Poland (grant No. 2 P05D 097 27). B.A.Z. expresses his gratitude to the Foundation for Polish Science (FNP, "Nestor") for providing an individual scientific grant. Thanks are due to Mr. Sven Moesgaard, Pharma Nord, Denmark, for supplying us with selenium-enriched yeast and placebo used in this study. 
Open Access This article is distributed under the terms of the Creative Commons Attribution Noncommercial License which permits any noncommercial use, distribution, and reproduction in any medium, provided the original author(s) and source are credited.

\section{References}

1. Kazi TG, Jalbani N, Kazi N, Jamali MK, Arain MB et al (2008) Evaluation of toxic metals in blood and urine samples of chronic renal failure patients, before and after dialysis. Ren Fail 30:737-345

2. Rucker D, Thadhani R, Tonelli M (2010) Trace element status in hemodialysis patients. Semin Dial, Jun 14 (Abstract)

3. Tonelli M, Wiebe N, Hemmelgarn B, Klarenbach S, Field C, Manns et al (2009) Trace elements in hemodialysis patients: a systematic review and meta-analysis. BMC Med 7:25

4. Taccone-Gallucci M, Noce A, Bertucci P, Fabbri C, Manca-di-Villahermosa S et al (2010) Chronic treatment with statins increases the availability of selenium in the antioxidant defence systems of hemodialysis patients. J Trace Elem Med Biol 24:27-30

5. Valko M, Rhodes CJ, Moncol J, Izakovic M, Mazur M (2006) Free radicals, metals and antioxidants in oxidative stress-induced cancer. Chem Biol Interact 160:1-40

6. Ames BN (2001) DNA damage from micronutrient deficiencies is likely to be a major cause of cancer. Mutat Res 475:7-20

7. Castro L, Freeman BA (2001) Reactive oxygen species in human health and disease. Nutrition 17:161-165

8. Mayne ST (2003) Antioxidant nutrients and chronic disease: use of biomarkers of exposure and oxidative stress status in epidemiologic research. J Nutr 133:933S-940S

9. Olinski R, Gackowski D, Foksinski M, Rozalski R, Roszkowski K et al (2002) Oxidative DNA damage: assessment of the role in carcinogenesis, atherosclerosis, and acquired immunodeficiency syndrome. Free Radic Biol Med 33:192-200

10. Zachara BA, Gromadzinska J, Wasowicz W, Zbrog Z (2006) Red blood cell and plasma glutathione peroxidase activities and selenium concentration in patients with chronic kidney disease: a review. Acta Biochim Pol 53:663-677

11. Combs GF Jr, Gray WP (1998) Chemopreventive agents: selenium. Pharmacol Ther 79:179-192

12. Schrauzer GN (2003) The nutritional significance, metabolism and toxicology of selenomethionine. Adv Food Nutr Res 47:73-112

13. Collins AR (2009) Investigating oxidative DNA damage and its repair using the comet assay. Mutat Res 681:24-32

14. Neve J, Chamart S, Molle L (1987) Optimization of direct procedure for the determination of selenium in plasma and erythrocytes using Zeeman effect atomic absorption spectroscopy. In: Bratter P, Schramel P (eds) Trace elements analytical chemistry in medicine and biology, vol 4. Walter de Gruyter, Berlin, Germany, pp 349-358

15. Singh NP, McCoy MT, Tice RR, Schneider EL (1988) A simple technique for quantitation of low levels of DNA damage in individual cells. Exp Cell Res 175:184-191

16. McKelvey-Martin VJ, Green MHL, Schmezer P, Pool-Zobel BL, De Meo MP et al (1993) The single cell gel electrophoresis assay (comet assay): a European review. Mutat Res 288:47-63

17. Palus J, Dziubaltowska E, Rydzynski K (1999) DNA damage detected by the comet assay in the white blood cells of workers in a wooden furniture plant. Mutat Res 444:61-74

18. Collins AR, Dobson VL, Dusinska M, Kennedy G, Stetina R (1997) The comet assay: what can it really tell us? Mutat Res 375:183-193

19. Morrison DF (1990) Multivariate statistical methods (Polish edn) PWN. Warsaw, Poland

20. Senesse P (2009) Nutrition and oncogeriatry. Cancer Radiother 13:628-631

21. Letavayova L, Vlckova V, Brozmanova J (2006) Selenium: from cancer prevention to DNA damage. Toxicology 227:1-14

22. Shamberger RJ, Willis CE (1971) Selenium distribution and human cancer mortality 2:211-221

23. Schrauzer GN, White DA, Schneider CJ (1977) Cancer mortality correlation studies-III: statistical associations with dietary selenium intakes. Bioinorg Chem 7:23-31

24. Bonomini M, Albertazzi A (1995) Selenium in uremia. Artif Organs 19:443-448

25. Zachara BA, Salak A, Koterska D, Manitius J, Wasowicz W (2004) Selenium and glutathione peroxidases in blood of patients with different stages of chronic renal failure. J Trace Elem Med Biol 17:291-299

26. Zachara BA, Adamowicz A, Trafikowska U, Trafikowska A, Manitius J et al (2001) Selenium and glutathione levels, and glutathione peroxidase activities in blood components of uremic patients on 
hemodialysis supplemented with selenium and treated with erythropoietin. J Trace Elem Med Biol 15:201-208

27. Richard MJ, Ducros V, Foret M, Arnaud J, Coudray C et al (1993) Reversal of selenium and zinc deficiencies in chronic hemodialysis patients by intravenous sodium selenite and zinc gluconate supplementation. Biol Trace Elem Res 39:149-159

28. Seo YR, Sweeney C, Smith ML (2002) Selenomethionine induction of DNA repair response in human fibroblasts. Oncogene 21:3663-3669

29. Fisinin VI, Papazyan TT, Surai PF (2009) Producing selenium-enriched eggs and meat to improve the selenium status of the general population. Crit Rev Biotechnol 29:18-28

30. Ferguson LR, Philpott M, Karunasinghe N (2004) Dietary cancer and prevention using antimutagens. Toxicology 198:147-159

31. Slupphaug G, Kavli B, Krokan HE (2003) The interacting pathways for prevention and repair of oxidative DNA damage. Mutat Res 531:231-251

32. Yu S, Paetau-Robinson I (2006) Dietary supplements of vitamins E and C and beta-carotene reduce oxidative stress in cats with renal insufficiency. Vet Res Commun 30:403-413

33. Tarng DC, Huang TP, Wei YH, Liu TY, Chen HW et al (2000) 8-hydroxy-2'-deoxyguanosine of leukocyte DNA as a marker of oxidative stress in chronic hemodialysis patients. Am J Kidney Dis 36:934-944

34. Moller P, Loft S (2002) Oxidative DNA damage in human white blood cells in dietary antioxidant intervention studies. Am J Clin Nutr 76:303-310

35. Sardas S, Izdes S, Ozcagli E, Kanbak O, Kadioglu E (2006) The role of antioxidant supplementation in occupational exposure to waste anaesthetic gases. Int Arch Occup Environ Health 80:154-159

36. Kan E, Undeger U, Bali M, Basaran N (2002) Assessment of DNA strand breakage by the alkaline COMET assay in dialysis patients and the role of Vitamin E supplementation. Mutat Res 520:151-159

37. Domenici FA, Vannucchi MT, Jordao AA Jr, Meirelles MS, Vannucchi H (2005) DNA oxidative damage in patients with dialysis treatment. Ren Fail 27:689-694

38. Stopper H, Treutlein AT, Bahner U, Schupp N, Schmid U et al (2008) Reduction of the genomic damage level in haemodialysis patients by folic acid and vitamin B12 supplementation. Nephrol Dial Transplant 23:3272-3279

39. Cho KH, Kim HJ, Rodriguez-Iturbe B, Vaziri ND (2009) Niacin ameliorates oxidative stress, inflammation, proteinuria, and hypertension in rats with chronic renal failure. Am J Physiol Renal Physiol 297:F106-F113

40. Dziaman T, Huzarski T, Gackowski D, Rozalski R, Siomek A et al (2009) Elevated level of 8-oxo-7, 8dihydro-2'-deoxyguanosine in leukocytes of BRCA1 mutation carriers compared to healthy controls. Int J Cancer 125:2209-2213

41. Collins AR (2004) The comet assay for DNA damage and repair. Principles, applications and limitations. Mol Biotechnol 26:249-261

42. Hartmann A, Agurell E, Beevers C, Brendler-Schwaab S, Burlinson B et al (2003) Recommendations for conducting the in vivo alkaline Comet assay. 4th International Comet Assay Workshop. Mutagenesis $8: 45-51$

43. Ribeiro DA, Campos RR, Bergamaschi CT (2009) Chronic renal failure induces genetic instability in multiple organs of Wistar rats. Eur J Clin Investig 39:289-295

44. Puchades Montesa M, Gonzalez Rico M, Solís Salguero M, Torregrosa Maicas I, Tormos Munoz M et al (2009) Study of oxidative stress in advanced kidney disease. Nefrologia 29:464-473

45. Tarng DC, Huang TP, Liu TY, Chen HW, Sung YJ et al (2000) Effect of vitamin E-bonded membrane on the 8-hydroxy 2'-deoxyguanosine level in leukocyte DNA of hemodialysis patients. Kidney Int 58:790-799

46. Schupp N, Stopper H, Rutkowski P, Kobras K, Nebel M et al (2006) Effect of different hemodialysis regimens on genomic damage in end-stage renal failure. Semin Nephrol 26:28-32

47. Stopper H, Boullay F, Heidland A, Vienken J, Bahner U (2001) Comet-assay analysis identifies genomic damage in lymphocytes of uremic patients. Am J Kidney Dis 38:296-301

48. Horoz M, Bolukbas FF, Bolukbas C, Aslan M, Koylu AO et al (2006) The association of circulating leptin level with peripheral DNA damage in hemodialysis subjects. Clin Biochem 39:918-922

49. Stewart JH, Buccianti G, Agodoa L, Gellert RT, McCredie MR et al (2003) Cancer of the kidney and urinary tract on dialysis for end-stage renal disease: analysis of data from the United States, Europe, and Australia and New Zealand. J Am Soc Nephrol 14:197-207

50. Schupp N, Schmid U, Heidland A, Stopper H (2008) New approaches for the treatment of genomic damage in end-stage renal disease. J Ren Nutr 18:127-133

51. Bellinger FP, Raman AV, Reeves MA, Berry MJ (2009) Regulation and function of selenoproteins in human disease. Biochem J 422:11-22

52. Reeves MA, Hoffmann PR (2009) The human selenoproteome: recent insights into functions and regulation. Cell Mol Life Sci 66:2457-2478 
53. Valdiglesias V, Pasaro E, Mendez J, Laffon B (2010) In vitro evaluation of selenium genotoxic, cytotoxic, and protective effects: a review. Arch Toxicol 84:337-351

54. Papp LV, Lu J, Holmgren A, Khanna KK (2007) From selenium to selenoproteins: synthesis, identity, and their role in human health. Antioxid Redox Signal 9:775-806

55. Squires J, Berry MJ (2006) Selenium, selenoproteins, and cancer. Hawaii Med J 65:239-240

56. Grotto D, Barcelos GRM, Valentini J, Antunes LM, Angeli JP et al (2009) Low level of methylmercury induce DNA damage in rats: protective effects of selenium. Arch Toxicol 83:249-254

57. Waters DJ, Shen S, Xu H, Kengeri SS, Cooley DM et al (2007) Noninvasive prediction of prostatic DNA damage by oxidative stress challenge of peripheral blood lymphocytes. Cancer Epidemiol Biomark Prev 16:1906-1910

58. Li GX, Lee HJ, Wang Z, Hu H, Liao JD et al (2008) Superior in vivo inhibitory efficacy of methylseleninic acid against human prostate cancer over selenomethionine or selenite. Carcinogenesis 29:1005-1012

59. Waters DJ, Shen S, Glickman LT, Cooley DM, Bostwick DG et al (2005) Prostate cancer risk and DNA damage: translational significance of selenium supplementation in a canine model. Carcinogenesis 26:1256-1262

60. Dziaman T, Huzarski T, Gackowski D, Rozalski R, Siomek A et al (2009) Selenium supplementation reduced oxidative DNA damage in adnexectomized BRCA1 mutations carriers. Cancer Epidemiol Biomark Prev 8:2923-2928

61. Letavayová L, Vlasáková D, Spallholz JE, Brozmanová J, Chovanec M (2008) Toxicity and mutagenicity of selenium compounds in Saccharomyces cerevisiae. Mutat Res 638:1-10

62. Mániková D, Vlasáková D, Loduhová J, Letavayová L, Vigasová D et al (2009) Investigations on the role of base excision repair and non-homologous end-joining pathways in sodium selenite-induced toxicity and mutagenicity in Saccharomyces cerevisiae. Mutagenesis 25:155-162

63. Schrauzer GN (2009) Selenium and selenium-antagonistic elements in nutritional cancer prevention. Crit Rev Biotechnol 29:10-17

64. Schrauzer GN (2001) Nutritional selenium supplements: product types, quality, and safety. J Am Coll Nutr 20:1-4

65. Schrauzer GN (2009) Lessons from the selenium and vitamin E cancer prevention trial (SELECT). Crit Rev Biotechnol 29:81

66. Rayman MP, Combs GF Jr, Waters DJ (2009) Selenium and vitamin E supplementation for cancer prevention. JAMA 301:39-51

67. Schrauzer GN (2000) Selenomethionine: a review of its nutritional significance, metabolism, and toxicity. J Nutr 130:1653-1656

68. Fischer JL, Mihelc EM, Pollok KE, Smith ML et al (2007) Chemotherapeutic selectivity conferred by selenium: a role of p53-dependent DNA repair. Mol Cancer Ther 6:355-361

69. Laffon B, Valdiglesias V, Pasaro E, Méndez J et al (2010) The organic selenium compound selenomethionine modulates bleomycin-induced DNA and repair in human leukocytes. Biol Trace Elem Res 133:12-19 